\title{
JUDICIAL REVIEW OF AND APPEALS FROM CONSERVATION BOARD ORDERS*
}

\begin{abstract}
This article discusses the remedies that are available to an oil and gas operator who has been adversely affected by an order of the Oil and Gas Conservation Board. It first analyzes statutory rights of appeal and then discusses the availability of the prerogative writs to review an order of the Conservation Board. An examination of the general principles of administrative law outlines the grounds upon which a Conservation Board order can be attacked and illustrates their possible application to orders of the Saskatchewan and Alberta Oil and Gas Conservation Boards.
\end{abstract}

\section{A. Introduction}

The Conservation Board of the Province of Alberta and the Minister of Mineral Resources, or the Lieutenant Governor in Council, as the case may be, of the Province of Saskatchewan, have each been granted specific powers, pursuant to their respective Oil and Gas Conservation Acts, enabling them to promulgate numerous types of orders affecting the petroleum and natural gas industry. The intention of this paper is to review briefly what remedies, if any, are available to a person who has been adversely affected by such an order. This topic practically covers the entire field of administrative law, but it is not the intention of this paper to review this field in detail.

At this point, it might clarify matters to set out briefly the constitution of the respective authorities and the powers granted to them. The paper will then deal with statutory rights of appeal, if any, and other remedies. Dealing first with the Province of Alberta, the Oil and Gas Conservation Board is a constituted body politic and corporate by virtue of Section 6 of the Oil and Gas Conservation Act. ${ }^{1}$ Sections 7 to 10 of the Act deal with the membership of the Board and the appointment thereof. Section 17 of the Act sets out the general powers of the Board and Sections 103, 105 and 109 outline some of the specific powers of the Alberta Oil and Gas Conservation Board.

In Saskatchewan, the Minister has the authority to make certain orders upon recommendation thereof by the Board, and the compulsory pooling order is such an example." Concurrent with the Minister's authority, the Lieutenant Governor in Council has been delegated authority to make certain orders upon recommendation thereof by the Minister after a hearing by the Board, and the compulsory unitization order is an example of this authority. ${ }^{3}$ Since the Lieutenant Governor only has authority to order the unitization of a field, or portion thereof, upon recommendation of the Minister, the occasions for conflict should be few. However, an example of conflicting orders and the remedy therefrom, if any, will be discussed in the latter part of this paper under the topic of declaratory judgments.

* This paper was prepared through the combined efforts of J. B. LOWERY, Solicitor, Imperial Oil Limited, Calgary, and J. L. SNITH, Solicitor, Pacific Petroleums Ltd. Calgary.

S.A. 1957 , c. 63

R.S.S. 1965 , c. 360 , s. 30.

3 Id., s. 35. 


\section{B. Statutory Rights of Appeal}

There is no statutory appeal under the Saskatchewan Act, and the only remedy that a person has against an adverse order made pursuant to the Act is by way of prerogative writs or a declaratory judgment. In Alberta, the statutory rights of appeal are set out in Sections 117 to 119 of The Oil and Gas Conservation Act. These sections provide for three types of statutory appeals, ${ }^{4}$ namely:

1. An appeal to the Board itself if the Board has made an order without holding a hearing, or having held a hearing has not given a person affected by the order, notice of the hearing. ${ }^{\circ}$

2. An appeal, to the Appellate Division of the Supreme Court of Alberta, upon leave of a Judge of that Court, from an order of the Board made pursuant to Section 37 of the Act. ${ }^{6}$

3. An appeal to the Appellate Division of the Supreme Court of Alberta from an order or direction made by the Board pursuant to Parts IV and V of the Act, which parts are entitled "Drilling and Production" and "Transportation and Disposition of Oil and Gas", respectively."

The Board sitting in appeal pursuant to Section 118 cannot be composed of the same members who made the order appealed from. ${ }^{8}$

An appeal from a Section 37 order" is made "by a person entitled to appeal" to the Appellate Division of the Supreme Court of Alberta upon leave first had and obtained from a judge of the Appellate Division. ${ }^{10}$ A "person entitled to appeal" for purposes of a Board order made under Section 37 is one who is "affected" by the order and who "appeared or was represented before the Board at the hearing upon which the order" was made. ${ }^{11}$ Subsection (1) of Section 119 appears to create a hiatus of persons entitled to appeal a Section 37 Board order. For example, if a person was adversely affected by a Section 37 Board order, but did not appear at the hearing because he was unaware of the hearing due to lack of notice, he apparently is not entitled to appeal to the Appellate Division of the Supreme Court. This seems paradoxical when another person who attended the hearing and was affected by the resulting order is able to appeal the order. This situation seems to violate one of the rules of natural justice ${ }^{12}$ which seems to be incorporated by inference in paragraph (c) of subsection (2) of Section 119.

It could be argued that a person affected who did not appear at a

4 See also Section 88 which provides that an order under Part VIII of the Act, "Unit Operations," can only be amended, revised, altered or revoked pursuant to the provisions of Section 74a.

5 S.A. 1957 . c. 63, s. $118(1)$ and $118(2)$

6 Id.. s. $119(2)$.

i Id., s. $119(3)$.

8 R. v. Alberta Securities Commission, Ex parte Albrecht, (1962) 36 D.L.R. (2d) 199: S. A. de Smith, Judicial Review of Administrative Action (1959), 147; $R$. v. Board of Arbitration, Ex parte Cumberland Railway Co., (1968) 67 D.L.R. (2d) 135; Szilard v. Szasz [1955] S.C.R. 3 .

$\checkmark$ Section 37 provides as follows:

In order to prevent waste, the Board may

(a) require the repressuring, recycling pressure maintenance or recovery enhancerequire the repressuring, recycling, pressure maintenance or recovery enhance-
ment in any pool or portion thereof, and for or incidental to such purpose require the introduction or injection into any pool or portion thereof of gas, air, water or other substances, and

(b) require that any gas be gathered, processed if necessary, and the gas or products therefrom marketed or injected into an underground. reservoir for storage or for any other purpose.

10 Supra, n. 5, s. $119(2)$.

11 Id., s. 119 (1).

12 "Audi Alteram Partem." 
hearing with respect to a Section 37 Board order because of lack of notice could apply to the Board to vary, amend or rescind the order pursuant to the provisions of Section $118(2)$. This is not very satisfactory since it is an appeal to the same tribunal, although composed of different members, and assumes that the person affected will know of the order within 45 days after its promulgation. If such a person applied to the Board within the limited time and the Board did vary the order, the further question arises of whether or not such a person is entitled to appeal to the Appellate Division of the Supreme Court? It would appear that unless this person's application to the Board resulted in a hearing and a further order was made pursuant to this hearing, such a person would not be "a person entitled to appeal" as contemplated in subsection (1) of Section 119.

There appears to be no requirement that the Board hold a hearing before making an order pursuant to Section 37. Even if a matter is contentious, the Board's only mandatory requirement is to give notice of receipt of an application or notice of a hearing, if there is to be one. ${ }^{13}$ If the Board does not hold a hearing, presumably the last portion of subsection (1) of Section 119 requiring a person entitled to appeal to attend the hearing becomes redundant and all persons affected by the order would be entitled to appeal to the Appellate Division of the Supreme Court upon obtaining the necessary leave.

Section 37 is contained in Part IV of the Act but since appeals from such orders are specifically dealt with in subsection (2) of Section 119 it must be presumed to be excluded from the provisions of subsection (3) of the same section. ${ }^{14}$ A person entitled to appeal under subsection (3) is defined only as a person affected and this definition is broader than that outlined for an appeal of a Section 37 Board order where the person affected must also be represented at the hearing before having a right to appeal. There is a further distinction in this type of appeal in that it is not necessary for the person affected to obtain leave from a judge of the Appellate Division.

The grounds for appealing a Section 37 Board order are as follows:

(a) that the Board lacked jurisdiction to make the order or direction;

(b) that there was insufficient or no evidence before the Board to enable it to make the order or direction made;

(c) that the order or direction was otherwise wrongly made. ${ }^{15}$

The grounds for appealing a Board order made under Part IV or Part $\mathrm{V}$ are "any question of jurisdiction or upon any question of law."16 At first glance it would appear that the legislature has attempted to provide different grounds of appeal for Section 37 Board orders from the grounds provided for Part IV and V orders. However, when subsections (2) and (3) of Section 119 are read in conjunction with subsection (15) for the same Section, it is difficult to see any distinction. It might be argued that paragraphs (a), (b) and (c) of subsection (2) are statutory enactments of prerogative writs and that really all that has been granted a person entitled to appeal is his right to prerogative writs

13 Supra, n. 5, s. $106(2)$.

14 "Generalia Specialibus Non Derogant", Maxwell on Interpretation of Statutes, (11th ed. 1962), at 168 .

15 Supra, n. 5, s. 119 (2).

16 Id., s. $119(3)$. 
in statutory form. If that were the case, then the Appellate Division would not be able to vary the Board order, but the Appellate Division is granted the specific right to direct that such order be varied. ${ }^{17}$ Therefore it is difficult to see the reasons for the wording of the grounds of appeal for a Section 37 Board order being different from the wording of the grounds of appeal for a Part IV or V order.

In 1960 the Act was amended to incorporate Section 38a, which states:

The performance of any act required to be done under section 37 or of any scheme approved under section 38 shall not be prevented or restrained by an injunction, judgment or order of any court.18

Does this mean that the right of appeal granted a person affected in Section 119 (2) has been taken away? If Section 38a is so inconsistent with Section 119 (2) that the two cannot stand together, then Section 119 (2) has been impliedly repealed by Section 38a. ${ }^{19}$ The result of a successful appeal under Section 119 (2) is not to restrain or prevent any act pursuant to an order of the Board, but rather to require the Board to alter its order. There is therefore no conflict between Section 38a and Section $119(2)$ and a person affected by a Section 37 Board order still has his right of appeal under Section $119(2)$.

\section{Right of Appeal by Prerogative Writs}

Since the Alberta Act gives a statutory right of appeal and Section 103 (2) of the Act provides that, subject to Sections 118 and 119, every Board order is final and is not subject to review in any court, the question arises whether or not an aggrieved person can appeal to the Courts by virtue of the prerogative writs and, if he can, must that person first exhaust his remedies under the Act?

Dealing firstly with the prerogative writs, the use of such writs is not considered to be a remedy by way of an appeal and the fact that Section 103 (3) of the Act purports to prevent review by the court of the Board's actions does not affect the common law rights of remedy by virtue of such writs. Parker, L.J. in R. v. Medical Appeal Tribunal, said:

Sometimes, as here, the statute provides that subject to a specific right of appeal the decision shall be final. In such a case it may be said that the expression 'shall be final' is merely a pointer to the fact that there is no further appeal, and the remedy by way of certiorari is not by way of appeal.20

In Camac Exploration Ltd. v. Oil and Gas Conservation Board of Alberta, ${ }^{21}$ the applicant attempted to have a Part IV Board order quashed by way of certiorari. The applicant claimed that the Board lacked jurisdiction because the applicant was not notified of the hearing and thus there had been a denial of natural justice. The respondent relied on the provisions of Sections 103 and 119 of the Act and indicated that the order could not be quashed by way of certiorari. In his decision Kirby, J. reviews numerous authorities and concludes with the following observation:

\footnotetext{
17 Id., s. 119 (15).

18 S.A. 1960,74, c. 8

10 Maxwell, Supra, n. 14, at 154

20 [1957| 1 Q.B. 574. at 589. See also Security Export Company v. Hetherington, [1923]

S.C.R. 539, per Duff. J., at 550 and per Anglin, J., at 566.

21 (1964) 47 W.W.R. 81 .
} 
In Canada it has been repeatedly held that an express statutory abolition of certiorari does not oust the power of the court to issue the writ or to quash a conviction if justices have acted without jurisdiction, for in such a case the inferior court has not brought itself within the terms of the statute taking away certiorari; even express words do not take away the supervising power of a Superior Court when there is want of jurisdiction in the inferior court. ${ }^{22}$

In the Camac case the applicant could not establish lack of notice, since the Board did provide notice by way of advertisement in various newspapers and Camac had appeared at the hearing and participated therein. Accordingly, there was no denial of natural justice and the order could not be quashed.

\section{(1) Must Appeal be Exhausted Before Certiorari Applies?}

Although the Act sets out the method of appeal from the Board's decision, it is not necessary to exhaust one's remedies under the Act before an appeal can be taken to the Court by way of certiorari. ${ }^{23} \mathrm{~S}$. A. de Smith, dealing with the question of recourse to the Courts by way of prerogative writs where a satutory right of appeal exists, states as follows:

On the one hand, there is a presumption against taking away the jurisdiction of the superior courts by implication; on the other hand, it is a general rule that where Parliament has created new rights and duties and has appointed a specific tribunal for their enforcement, recourse must be had to that tribunal alone. If the words establishing the new machinery are construed as requiring the parties to make use of it-and this construction will generally be given to a provision that the matter "shall be determined by" the appointed tribunal-the jurisdiction of the courts is ousted until the statutory process has been completed, except insofar as they may entertain an application to prohibit the tribunal from proceeding further on the ground that it has no jurisdiction to determine a particular matter. Subject to this exception, the courts will be unable to assume jurisdiction at this stage, even with the consent of all parties. ${ }^{24}$

The Alberta Oil and Gas Conservation Act uses the permissive word "may","s and as such it is not necessary to exercise one's right of appeal under the Act before applying for an order for certiorari, otherwise Kirby, J. would have been without jurisdiction in the Camac case ${ }^{26}$ to entertain an application for certiorari. It is submitted that in Alberta, the right of appeal provided for in the Act exists concurrently with the prerogative writs remedy and the choice of which remedy to follow would depend upon the result desired. ${ }^{2 \pi}$

\section{(2) Powers of Court on Appeal}

Section $117(15)$ of the Oil and Gas Conservation Act grants the appeal court a greater power than it possesses by way of review by prerogative writs because the appellate tribunal is granted the power not only to confirm or set aside the order or direction appealed from, but also to direct that it be varied. On an application for certiorari or other prerogative writ, the function of the court has been stated as follows:

The Court of King's Bench has an inherent jurisdiction to control all inferior tribunals, not in an appellate capacity, but in a supervisory capacity. This control extends not only to seeing that the inferior tribunals keep withing their jurisdiction, but also to seeing that they observe the law. The control is

22 Id., at 84-85.

23 See Ex parte Weston, [1960] O.W.N. 7; Samuels v. A.G. of Canada, (1956) 1 D.L.R. (2d) 110; Re Wilfong, (1962) 32 D.L.R. (2d) 447.

24 S. A. de Smith, Supra, n. 8, at 224.

25 Supra, n. 5, ss. 117-119.

20 Supra, n. 21.

27 See Morden, Recent Developments in Administrative Law, 1966 Law Society of Upper Canada Special Lectures 275, at 334-335. 
exercised by means of a power to quash any determination by the tribunal which, on the face of it, offends against the law. The King's Bench does not substitute its own reviews for those of the tribunal, as a Court of Appeal would do. It leaves it to the tribunal, to hear the case again and in a proper case may command it to do so. 28

\section{(3) Appeal does not Stay Board Order}

Although an order of the Board may be appealed either by virtue of the right granted by the Act or by certiorari, the order continues to operate unless the Board orders otherwise. Section $119(6)$ provides as follows:

An order or direction of the Board takes effect at the time prescribed by the order or direction, and its operation is not suspended by any appeal to the Appellate Division, or by any further appeal, but the Board itself may if it thinks fit suspend the operation of its order, when appealed from, until the decision of the Appellate Division or other appellate tribunal is rendered.

It is submitted that once an appeal is taken the order should be suspended. In England, the Rules of the Supreme Court provide for suspension of the decision appealed from by way of certiorari, but the Alberta Supreme Court Rules do not contain a similar provision. Rule 1(6) of the English Rules provides as follows:

The grant of leave under this rule to apply for an order of prohibition or an order of certiorari, shall, if the Court or a Judge so directs, operate as a stay of proceedings in question until the determination of the application or until the Court or Judge otherwise orders. ${ }^{20}$

(4) Res Judicata

Are decisions of the Oil and Gas Conservation Board res judicata? It would appear that the rule of res judicata applies not only to judicial tribunals but to administrative tribunals exercising judical functions. ${ }^{30}$ S. A. de Smith makes the following observations in this regard:

The characteristic attribute of a judical act or decision is that it binds, whether it be right or wrong. An error of law or fact committed by a judicial body cannot, in general, be impeached otherwise than on appeal unless the erroneous determination relates to a matter on which the jurisdiction of that body depends, or unless an error of law is apparent on the face of the record of a determination made by it (in which case the decision may be quashed by certiorari). These principles govern judicial review not only of the findings of inferior courts sticto sensu, but also of the findings of administrative bodies which are held to be acting in a judicial capacity. Such bodies are deemed to have been invested with power to err within the limits of their jurisdiction; and provided that they keep within those limits, their decisions may be res judicatae. ${ }^{31}$

It is submitted that any order made pursuant to Section 37 or Parts III or IV of the Alberta Act would require a judicial decision, and any such order made would ordinarily be res judicata. However, Section 117 of the Act states:

The Board may review, rescind, change, alter or vary any order or direction made by it, or may rehear any application before deciding it.

It would seem that, regardless of the common law rule relating to res judicata, Section 117 overrules it. Similarly the Board would not be governed by stare decisis. Stewart, J. in the Ontario High Court decision of Re Thibault et al v. C.L.R.B. said:

2× Denning. L.J. in R. v. Northumberland Compensation Appeal Tribunal, Ex parte Shaw [1952] 1 K.B. 338 at 347, see also Macdonald, C.J.A. in Fletcher v. Wade, [1919] 2 W.W.R. 1, at 2 .

23 The Supreme Court Practice (1957), Vol. 1, Order 53, at 690.

30 Contra, Re Fernie Memorial Hospital Society and Duthie, (1963) 42 W.W.R. 511.

31 S. A. de Smith, Supra, n. 8, at 63. 
Perhaps it is desirable if the rule of stare decisis applied to administrative Boards, but it is not for me, upon an application and certiorari, to determine which of two confliciting decisions is correct. 32

Morden points out the desirability of having administrative stare decisis $^{33}$ and refers to two cases giving encouragement to such procedure. $^{34}$ In Alberta Board Decision 68-7, dated April 2, 1968, one of the examiners gives his reasons for refusing to grant an application, but states as follows:

Notwithstanding the above, in applying Decision No. 68-3 to the subject application, the application does not appear to differ from those considered in that decision in any significant way.

Presumably on the basis of this statement, the examiner then recommends that the application be granted. This is certainly an attempt at stare decisis and the Board in its reasons for Decision 68-7 indicates that if all the conditions in the application relative to Decision 68-7 were the same as those in Decision 68-3 it "would make a similar finding."

The Saskatchewan Oil and Gas Conservation Act does not provide for a method of appealing the Minister's order. On the other hand, it does not attempt to prohibit an appeal by way of certiorari or otherwise. Thus it would appear that the only remedies available to question an order of the Minister are those provided in the general field of administrative law.

\section{(5) Additional Appeal Tribunals}

It is interesting to note that, in some of the United States, an additional Board is set up to review the decisions of the "Conservation Board". In Ohio, ${ }^{35}$ an Oil and Gas Board of Review is appointed by the Governor. It consists of five members appointed for five-year terms, whose appointments are so staggered that one new member is appointed each year. Each appointee is a representative of one of the following, namely; a major petroleum company, the public, the independent petroleum operators, oil and gas lawyers and geologists, and not more than three members shall be members of the same political party. In California, ${ }^{36}$ similar review boards exist in each of the six designated districts consisting of five District Commissioners in five of the districts and seven in another. The Commissioners are elected every three years by the taxpayers. Eligibility for election is residency in the district and engagement in oil and gas development or production. A Commissioner is specifically forbidden to vote on any matter in which he has an interest. The value of such review boards is questionable inasmuch as they result in a further board from which to appeal.

\section{Administrative Law}

Before prerogative writs are available as a means of appeal, the orders of the Board, Minister or Lieutenant Governor in Council, as the case may be, must be characterized as "judicial". ${ }^{37}$ There are many tests to determine whether a tribunal must act judicially ${ }^{38}$ and for our pur-

32 (1957) 7 D.L.R. (2d) 526, at 529.

33 Supra, n. 27, at 282-285.

34 Re Hopedale Developments Ltd. and Town of Oakville, [1965] 1 O.R. 259 (Ont. C.A.)

and C.N.R. v. Bell Telephone et al, [1939] S.C.R. 308.

35 Page's Ohio Rev. Code Ann., s. 1509.35.

3 is Thornton, The Law of Oil and Gas, 5th ed., Vol. 4, p. 1919

37 S. A. de Smith, Supra, n. 8, at 34 .

38 Id., at 37, et seq. Whether the order is binding, conclusive, imposes obligations, etc. 
poses it would appear that the Alberta Conservation Board is one of these tribunals. In the Camac case ${ }^{30}$ the Board did not suggest that it was not required to act judicially and had the same been successfully contended, Kirby, J. would not have had to deal with the problem of notice as it applied to certiorari.

Since the Board in Saskatchewan does not make orders, but rather makes recommendations to the Minister who then may make the order or in other instances, recommended that the Lieutenant Governor in Council make the order, the question arises as to whether the Saskatchewan Board must act judicially? Since the Board is merely an advisory, deliberative or investigatory body, it would not normally be held to be acting in a judicial capacity ${ }^{40}$ and hence the prerogative writs would not apply to its function. However, the order resulting from the Board's investigation appears ${ }^{41}$ to be subject to certiorari or prohibition and thus the person aggrieved would have to wait for the order to issue before applying for certiorari or wait until the Board's hearing is completed before applying for prohibition.

The following discussion on prerogative writs applies to the Board in the Province of Alberta and applies to the Minister or the Lieutenant Govenor in Council, as the case may be, in the Province of Saskatchewan. The normal prerogative writs are certiorari, prohibition and mandamus, and their function has been described as follows:

Prohibition will be appropriate to restrain a tribunal which assumes or threatens to assume a jurisdiction which it does not possess, so long as there is something in the proceedings left to prohibit; mandamus will be appropriate to compel a tribunal to exercise a jurisdiction which it has but declines to exercise; certiorari will be appropriate to quash the decision of a tribunal which has assumed a jurisdiction which it does not possess. ${ }^{22}$

Morden suggests that there are three basic grounds upon which the order or decision of a tribunal can be attacked, namely:

(i) Collateral Matters: No tribunal can, by a wrong decision, acquire jurisdiction.

(ii) Error of Law on the Face of the Record.

(iii) The Rules of Natural Justice:

(a) Bias.

(b) The Right of a Hearing.

(c) Legislative Intervention. ${ }^{43}$

\section{(1) Collateral Matters}

Perhaps the decision of The Queen v. Leong $\mathrm{BaChi} \mathrm{Ch}^{44}$ best illustrates the principle of defect of jurisdiction or collateral matters. In that case, the Immigration Act granted the Governor-in-Council certain regulatory powers with respect to immigration. Pursuant to that power, the following regulation was made:

From and after the 16th of August and until otherwise ordered, the landing in Canada of any immigrant of any Asiatic race is hereby prohibited, except as hereinafter provided:

The Immigration Officer-in-Charge may admit any immigrant who otherwise complies with the provisions of the Immigration Act, if it is shown to his satisfaction that such immigrant is-

39 Supra, n. 21.

40 Supra, n. 38.

42 Halsbury's Laws of England, 3rd Ed., Vol. II, p. 54-55.

43 Morden, Supra, n. 27, at 275. See also Yardley, The Grounds for Certiorari and Prohibition, (1959) 37 Can. Bar. Rev. 294.

44 [1954] S.C.R. 10. 
The wife, the husband, or the unmarried child under twenty-one years of age of any Canadian citizen legally admitted to and resident in Canada, who is in a position to receive and care for his dependants. ${ }^{45}$

The Immigration Officer refused to consider the application of the respondent to be admitted into Canada on the grounds that the respondent was illegitimate and therefore not the "child" of a Canadian citizen. Evidence was presented in court showing the respondent's legitimacy under Chinese law, which law would be recognized in Canada. The Supreme Court thus affirmed a judgment issuing a mandamus directing the Immigration Officer to carry out his statutory duty and determine whether the respondent child otherwise qualified under the Act.

An example of this "defect of jurisdiction" or "collateral matter" as it applies to the Alberta Oil and Gas Conservation Board might be an Order or refusal to hear an application under the compulsory pooling provisions. ${ }^{40}$ The Board only has jurisdiction under this section to make an order, with the approval of the Lieutenant Governor in Council, upon application by an "owner". An owner is defined in Section 71 and involves the interpretation of legal rights. If in fact the applicant is not an "owner" then the Board has no jurisdiction and the appropriate remedy would be prohibition if the order has not issued or certiorari if the order has issued. If the applicant is an owner and the Board refuses to hear the application, then the appropriate remedy would be mandamus.

\section{(2) Error of Law on the face of the Record}

The next broad principle for reviewing decisions of tribunals is "error of law on the face of the record". ${ }^{4}$ If the tribunal is acting within its jurisdiction its order may still be quashed by way of certiorari if an error of law is disclosed on the record. This brings into focus the meaning of the word "record" and an excellent discussion of its meaning is contained in an article written by Professor Albert S. Abel. ${ }^{48}$ For purposes of this paper we will content ourselves with the meaning ascribed by Denning, L.J. in R. v. Northumberland Compensation Appeal Tribunal, Ex parte Shaw, as follows:

I think the record must contain at least the document which initiates the proceedings; the pleadings, if any, and the adjudication; but not the evidence, nor the reasons, unless the tribunal chooses to incorporate them. If the tribunal does state its reasons and those reasons are wrong in law, certiorari lies to quash the decision. ${ }^{49}$

In the Northumberland case the tribunal was to award compensation for loss of employment and erred in calculating the compensation by not taking into consideration all of the applicant's former local government service. At the trial, counsel for the tribunal admitted there was error on the face of the record but contended that certiorari would lie only in the case of want or excess of jurisdiction. The case was tinus decided only on the basis of error on the face of the record and Denning, L.J. said:

Until about 100 years ago, certiorari was regularly used to correct errors of

45 Id., at 11.

46 Supra, n. 5, s. 73

47 Supra, n. 43.

48 Abel. Materials Proper for Consideration in Certiorari to Tribunals, (1963) 15 University of Toronto Law Journal 102

49 [1952] 1 K.B. 338 , at 352 . 
law on the face of the record. It is only within the last century that it has fallen into disuse, and that is only because there has, until recently been little occasion for its exercise. Now, with the advent of many new tribunals, and the plain need for supervision over them recourse must once again be had to this welltried means of control.50

At most Board hearings for both Alberta and Saskatchewan a reporter is present to record the proceedings although in neither case is such procedure mandatory. Section 117 (a) of the Alberta Act refers to "the transcript, record and findings" and indicates that they are the only items to be brought to the attention of the Appellate Division upon a statutory appeal of the Board's decision, but this Act does not make it mandatory for the Board to transcribe its proceedings. If a person contemplated a statutory appeal of an Alberta Board order relating to Part IV or V of the Act, then he would be advised to ensure that a court reporter was present to transcribe the proceedings:

... where solicitors expect to appeal, it is their business to have the evidence taken, so that the evidence can be brought before this Court.s1

From Denning, L.J.'s judgment in the Northumberland case the evidence at a Board hearing would only be part of the record if the Board incorporated the evidence in its adjudication. The Board normally does not incorporate the evidence in its adjudication and thus the evidence would rarely be available to show error of law. The transcript normally relates to evidence and not to law and affidavit evidence is not admissible to show the error of law on the record. ${ }^{32}$ On the other hand, affidavit evidence is not only admissible, but is usually required when the order is attacked on the grounds of excess or want of jurisdiction. ${ }^{53}$

If either of the relevant tribunals of Alberta or Saskatchewan recited points of law in its adjudication, as has been done, for example, by the Public Utilities Board in its decision No. 25564 dated June 22, 1961, and its interpretation or use of that law is wrong, then certiorari would lie. This particular type of error becomes somewhat meaningless when the record consists mainly of the Board's order with no reasons or law contained therein.

Another example of this type of error might be that potentially exhibited in Alberta Board Decision 68-7, dated April 26, 1968. The findings of one of the examiners was "while the incidence of the rule of capture is modified by spacing regulations, it still holds." This is true, but it is a statement of law and could be wrong. The Board in stating its reasons for Decision 68-7 considered a previous Decision (68-3) in which "the Board found no evidence that correlative rights" would be affected. While this statement does not pertain to Decision 68-7 it could have a bearing on Decision 68-3 if the same statement was made in this latter Decision. In certiorari applications it is a question of law whether there is any evidence with respect to an essential point and the determination of this aspect lies with the courts. On the other hand, if there is any evidence, the weight to be given such evidence is exclusively

50 Id., at 348 .

1 Irving, J.A. in Stancliffe v. Vancouver, (1912) 18 B.C.R. 629; see also Dokendorff v. Johnson, [1924] 3 W.W.R. 207.

62 Supra, n. 49.

s3 Ibid. 
within the jurisdiction of the Board. Lord Summer in R. v. Nat Bell Liquors said:

On certiorari, so far as the presence or absence of evidence becomes material, the question can at most be whether any evidence at all was given on the essential point referred to. Its weight is entirely for the inferior Court. ${ }^{5 t}$

\section{(3) The Rules of Natural Justice}

The term "natural justice" is in fact a collective term for several grounds of certiorari. It has been stated that there are in fact four rules of natural justice for breach of which certiorari is available: (a) audi alteram partem, (b) no interest, (c) reasonableness, and (d) no fraud..$^{55}$

The first rule, audi alteram partem, requires the tribunals to give the person affected a chance to be heard. ${ }^{56}$ Expressed another way it means there must be notice. ${ }^{57}$ The second rule means that there must be no interest, pecuniary or bias, on the part of the tribunal. ${ }^{58}$ The existence of "reasonableness" as a ground for certiorari is disputed"s and for purposes of this article we have assumed it not to exist. While fraud is an established ground for certiorari and is self-explanatory, the possibility of its application is too remote for discussion in this article

\section{(a) Audi Alteram Partem}

The Saskatchewan Act is silent regarding the requirement for notice and thus presumably this ground is available for certiorari with respect to orders resulting under the Saskatchewan Act. The Alberta Act makes specific reference to notice and hearings in Section 105, as follows:

Unless it is otherwise expressly provided by this Act to the contrary, any order or direction that the Board is authorized to make, may be made upon its own motion or initiative, and without the giving of any notice, and without holding any hearing.

Section 105 thus dispenses with notice or a hearing unless the provisions of the Act governing the order provide otherwise. But all "contentious" matters require notice ${ }^{60}$ and since "contentious" is not defined in the Act, nearly all Board Orders would require notice because of the latent propensity of such orders being "contentious".

\section{(b) No Interest}

Pecuniary interest as a ground for certiorari is obvious and is specifically incorporated in both the Alberta and Saskatchewan Acts respectively. ${ }^{61}$

\section{(4) Declaratory Judgment}

A declaratory judgment is a judgment of the court declaring the law without pronouncing sanctions against anyone. It is particularly useful in cases where a legal dispute exists but where no wrongful act has been committed entitling either party to consequential relief. There are several

54 [1922] 2 W.W.R. 30, at 44.

55 Yardley, Supra, n. 43, at 311 . Works, (1863) 14 C.B.N.S. 180

57 Alliance des Professeurs Catholique de Montreal v. Labour Relations Bd. of Que and Montreal Catholic School Comm., [1953| 2 S.C.R. 140.

58 Yardley, Supra, n. 43, at 316.

5i Id., at 319 .

60 Supra, n. 5, s. $106(2)$.

61 Alta., s. 8: Sask., s. 7(6). 
disadvantages to an application for certiorari which are not present in an application for a declaratory judgment; in an application for certiorari the applicant may not ask for other relief, examine for discovery, request a decision on the merits, etc. ${ }^{22}$

The Ontario Court of Appeal in Hollinger Bus Lines Limited v. Ontario Labour Relations Board ${ }^{63}$ indicates that an action for a declaratory judgment does not lie where the relief sought was obtainable by way of prerogative writs. However a contrary view is held in Alberta and Manitoba whereby the respective courts have held that a declaratory judgment will lie in circumstances where certiorari would also lie. ${ }^{64}$ The Saskatchewan King's Bench division although predating the Hollinger Bus Lines case comes to the same conclusion as follows:

True this Court has a supervisory authority over inferior Courts and over tribunals not strictly Courts but performing judicial functions, but how is that jurisdiction exercised? In my opinion it is exercised through the writs of prohibition, mandamus and certiorari. ${ }^{65}$

Unless the Act creating the tribunal makes the tribunal's decision 'final' or 'conclusive' or by the use of other words ousts the Court's jurisdiction, the court retains its original jurisdiction. ${ }^{60}$ Except for Part IV or V orders of the Board, the Alberta Act has ousted the court's original jurisdiction $^{07}$ and therefore an action for a declaratory judgment in Alberta would only lie with respect to a Part IV or V order. In Saskatchewan, the Act appears not to have excluded the courts original jurisdiction. It should thus follow that the Courts have concurrent original jurisdiction with the Minister or the Lieutenant Governor as the case may be.

Macdonald, J. in the Credit Foncier ${ }^{68}$ case has excluded the supervisory aspect of a declaratory judgment when the remedy could be obtained by way of prerogative writ. He did not, however, exclude the courts original jurisdiction. It may be that this is the only remedy available to a person affected by conflicting orders of the Minister and Lieutenant Governor in Council. For example, the Minister compulsorily pooled certain portions of land in Saskatchewan by order dated February 21, 1963 and published in the Saskatchewan Gazette dated March 15, 1963. Pursuant to this order provision was made for the operatorship of the pooled lands and the allocation of production to the various owners within the pooled lands. Subsequent to the Minister's order, the Lieutenant Governor in Council ordered that certain lands including the pooled lands be unitized. ${ }^{69}$ The Lieutenant Governor's order also provided for the operatorship of the unitized lands and the allocation of production within the unitized lands. If a well in the compulsorily pooled lands is producing at a high rate since it is now also unitized, on what basis should the production be allocated to the owners within the pooled lands? Should it be allocated on the basis of actual production or should it be allocated on the basis indicated in the

62 See Warren, The Declaratory Judgement: Reviewing Administrative Action, (1966) 44 Can. Bar Rev. 610.

3) (1952] O.R. 366. Charter Airways Limited Y A. G. for Canada and the Air Transport

Board et al. (1956) 1 D.L.R. (2d) 110 (Aita. C.A.), Klymchuk v. Cowan (1964), 45 D.L.R. (2d) 587 (Man. Q.B.).

6: Credit Foncier Franco-Canadien v. Board of Review, [1940] 1 D.L.R. 182, at 185.

ob Warren, Supra, n. 62, at 633 .

o7 Supra, n. 5, s. $103(2)$.

68 Supra, n. 65 . 
Lieutenant Governor's order. This is not merely of academic interest since a royalty owner in the pooled lands may well insist that his royalty be based on actual production if that is to his advantage, or on allocated production if that is to his advantage. The confict in operatorship is a minor problem in comparison but could be of importance to a small operator who wanted to maintain personnel in a certain area to look after the pooled lands and also other lands.

If the Minister and the Lieutenant Governor are each acting within their delegated authority and no prerogative writ remedy is available against either, it would appear that the only remedy available to the affected person would be an action for a declaratory judgment.

... [T]here are some classes of disputes which arise exclusively or predominant-

iy between public authorities and which cannot be judicially determined except

by means of a judgment in declaratory form. ${ }^{70}$

Warren lists numerous advantages of the declaratory judgment over the prerogative writs. Some of these are:

1. The declaration applies to both administrative and judicial acts and thus it is not necessary to inquire into the distinction between these two types of acts.

2. A declaration will review errors of law whether they appear on the face of the record or not.

3. A declaration will not only quash the decision of a tribunal but also remove doubts as to the meaning of a tribunal's decision.

4. In some Provincesi1 the rules of practice limit the time for applying for certiorari to within 6 months after the decision. ${ }^{72}$

\section{(5) Injunction}

With respect to Part IV and V orders of the Alberta Board, the remedy of injunction seems to exist concurrently with prohibition or mandamus. With respect to other orders it probably exists concurrently with prohibition or mandamus. ${ }^{i 3}$ If the Board acts in excess of or want of jurisdiction, the restriction on injunction should be as meaningless as the restriction on certiorari. ${ }^{i 4}$ In Saskatchewan, an injunction would not be available to prohibit the Minister or Lieutenant Govenor in Council from making an order, but may be available to restrain the Board from holding a hearing or making a recommendation. ${ }^{75}$

The equitable remedies, injunction and declaration, are not restricted to judicial functions and are therefore more flexible than the common law prerogative writs. However, by the time these equitable remedies were used to control tribunals, the common-law remedies were too firmly entrenched to be easily ousted and it may be difficult to convince a court that an injunction is an alternative remedy to prerogative writs. ${ }^{76}$ If a person needs to prohibit some act or order of the Alberta Board it may be wise to claim an injunction and an order of prohibition in the same action in case the act or order is classified as administrative in which event prohibition would not lie. ${ }^{77}$

70 S. A. de Smith, Supra, n. 8, at 385.

i1 See Rule 742, Alberta Rules of Court, 1968.

72 Warren, Supra, n. 62, at 641-644.

73 Supra, n. 64.

76 S. A. de Smith, Supra, n. 8, at 359.

70 Id., at 323

77 Id., at 363 . 


\section{E. Conclusion}

There appear to be numerous remedies available to persons adversely affected by a decision or order of the relevant authority. The paucity of cases leads one to the conclusion that very few persons are adversely affected by such decisions or orders or that the authorities in question always act within their jurisdiction. The better view is that operators have to live with the Crown if they want to continue operating. When the Crown is not only the regulatory authority but in many instances the lessor, the operator is reluctant to test the Crown's regulatory authority.

This reluctance should not apply to freehold mineral owners and perhaps when sufficient of them have been adversely affected by such decisions or orders we will experience an influx of judicial opinion concerning the decisions of these tribunals. 